\title{
ANALISIS SIFAT FISIK DAN KUALITAS AIR PENYARINGAN MEMBRAN KERAMIK ZEOLIT, LEMPUNG, ARANG BATOK KELAPA DENGAN VARIASI SUHU SINTERING
}

\author{
Wahyu Tri Ardhana ${ }^{1 *}$, Sri Mulyo Bondan Respati ${ }^{1}$, Suwardiyono $^{2}$ \\ ${ }^{1}$ Jurusan Teknik Mesin, Fakultas Teknik, Universitas Wahid Hasyim \\ ${ }^{2}$ Jurusan Teknik Kimia, Fakultas Teknik, Universitas Wahid Hasyim \\ Jln. Menoreh tengah X/22 Sampangan, Semarang, Indonesia \\ *Email: wahyu3ardhana@gmail.com
}

\begin{abstract}
Abstrak
Air yang tercemar dan terkontaminasi oleh logam berat biasanya disebabkan karena pembuangan limbah industri dan rumah tangga yang sembarangan. Filter air yang murah, efisien dan ramah lingkungan diperlukan untuk mengurangi kadar kandungan air dengan menggunakan teknologi membran. Selain membran keramik bisa menyerap fluida, membran keramik juga lebih tahan terhadap perubahan suhu yang tinggi, koros, dan kontaminasi bahan lain, sehingga membran keramik dapat digunakan sebagai media filter yang baik. Material yang sering digunakan dalam pembuatan filter keramik terdiri dari material campuran seperti zeolit, lempung dan arang batok kelapa. Tujuan penelitian ini untuk mengetahui sifat fisik dan kandungan kualitas air hasil penyaringan membran keramik zeolit, lempung dan arang batok kelapa dengan variasi suhu sintering. Penelitian ini menggunakan perhitungan susut volume, susut massa, bulk densitas, archimedes densitas, porositas, laju aliran air dan nilai TDS (Total Dissolved Solids), serta pegujian kandungan air hasil penyaringan dengan alat uji ICP-OES (Inductively Coupled Plasma-Optical Emission Spectrometry). Hasil penelitian ini menunjukkan bahwa semakin tinggi suhu sintering maka semakin besar penyusutan terhadap volume dan massa sehingga nilai densitas dan porositas semakin tinggi, semakin besar laju aliran air dan semakin rendah nilai TDS, serta penurunan kandungan unsur logam yang terdapat pada air hasil penyaringan. Sehingga dapat disimpulkan bahwa suhu sintering memberikan pengaruh yang signifikan terhadap sifat fisik dan kandungan kualitas air hasil penyaringan membran keramik zeolit, lempung dan arang batok kelapa.
\end{abstract}

Kata Kunci: arang batok kelapa, kualitas air,lempung, sifat fisik, sintering, zeolit.

\section{PENDAHULUAN}

Dewasa ini kesadaran masyarakat di Indonesia akan air layak minum semakin tinggi. Tidak semua air layak minum karena terdapat air yang sudah tercemar. Air yang tercemar dan terkontaminasi oleh logam berat biasanya disebabkan karena pembuangan limbah industri dan rumah tangga yang sembarangan. Standar kandungan unsur mineral atau TDS (Total Dissolved Solids) menjadi acuan syarat kriteria air bersih yang perlu diperhatikan. Air yang layak konsumsi untuk minum memiliki kadar TDS 10-100 ppm dan tidak mengandung mineral yang tinggi. Untuk mengurangi kadar kandungan air diperlukan filter air yang murah, efisien dan ramah lingkungan yaitu dengan menggunakan teknologi membran (Wahyuni, 2010).

Membran keramik adalah senyawa non organik yang tersusun dari unsur logam dan non logam. Keramik adalah keramik yang mempunyai rongga-rongga kecil yang menyebabkan fluida (porinya $\sim 30-70 \%$ ) dapat masuk ke dalam membran. Kelebihan membran keramik adalah selain dapat menyerap fluida, membran keramik juga relatif lebih tahan terhadap perubahan suhu tinggi, korosi dan kontaminasi bahan lain, sehingga dapat digunakan sebagai media filter yang sangat spesifik. Kualitas suatu produk keramik sangat ditentukan oleh jenis, komposisi, ukuran partikel dan temperatur sintering (Sebayang \& Tetuko, 2012). Material yang sering digunakan dalam pembuatan filter keramik terdiri dari material campuran seperti zeolit, tanah lempung dan arang batok kelapa.

Zeolit merupakan batuan atau mineral alam kimiawi tergolong mineral silika dan alumina silika terhidrasi berbentuk halus dan merupakan hasil produk sekunder yang stabil 
pada kondisi permukaan karena berasal dari proses sedimentasi, pelapukan maupun aktivasi hidrotermal. Zeolit telah banyak diaplikasikan sebagai absorben, penukar ion dan sebagai katalis. Tanah Lempung mengandung hidrated aluminium silica $\left(\mathrm{Al}_{2} \mathrm{O}_{3}, \mathrm{SiO}_{2}, \mathrm{H}_{2} \mathrm{O}\right)$ memiliki fungsi untuk campuran agar mudah dalam pembentukan keramik, karena karakternya yang plastis, daya ikat tinggi dan tanah lempung dicampur dengan kuarsa bertujuan untuk mengurangi retak pada saat dikeringkan (Arifin, 2009).

Arang batok kelapa digunakan sebagai zat aditif. Arang batok kelapa salah satu bahan terbaik sebagai karbon aktif karena karakternya yang memiliki banyak mikro pori, rendah kadar arangnya, tinggi kelarutan dalam airnya dan tinggi reaktivitasnya, maka dari komposisi batok kelapa itu dapat digunakan sebagai salah satu bahan baku pembuatan keramik (Pambayun dkk., 2013). Pengujian sifat fisik dari membran pada keramik meliputi susut volume, susut massa, densitas dan porositas. Selain itu pengujian kualitas air diperlukan untuk mengetahui kandungan unsur logam air hasil filter membran keramik.

\section{KAJIAN TEORI}

Keramik adalah paduan antara logam dan non logam yang dibuat dari bahan anorganik dengan proses melalui pembakaran di suhu tinggi. Karakteristik yang digunakan untuk berbagai aplikasi yaitu konduktivitas panas yang rendah, sifat listriknya dapat insulator, semi konduktor, konduktor bahkan super konduktor, sifatnya dapat magnetik dan non magnetik, keras dan kuat, namun rapuh, titik leleh tinggi dan tahan korosi (Wendari dkk., 2019).

Zeolit merupakan bahan mineral yang terdiri dari aluminium, silikon dan oksigen. Karakteristik tersebut antara lain adalah sebagai berikut (Akbary, 2009):

a. Pori zeolit dapat menyimpan molekul serta dapat menyeleksi ukuran molekul tertentu.

b. Sebagai penyeleksi pertukaran ion.

c. Zeolit merupakan zat yang stabil dalam keadaan tertentu.

d. Sebagai katalis solid bersifat asam.

Tanah lempung merupakan suatu mineral yang terbentuk dari batuan sedimen alumina silikat seperti $\mathrm{Al}, \mathrm{Fe}, \mathrm{Mg}$ dan $\mathrm{Si}$ (Tambunan, 2008). Tanah lempung terdiri dari fire clay, brick clay, ball clay dan kaolin. Tanah lempung mengandung beberapa unsur lain, seperti silikon dan oksigen. Tanah lempung dapat ditemukan di daerah yang banyak mengandung air dan lembap seperti di rawarawa, danau, sungai dan lain sebagainya. Batok kelapa merupakan bahan yang memiliki kualitas baik yang digunakan sebagai arang aktif. Karbon aktif merupakan bahan yang terdiri dari karbon amorf, karbon bebas dan memiliki kemampuan daya serap yang baik (Salamah, 2008).

Sintering adalah suatu proses pemadatan material dengan pemanasan temperatur tinggi mendekati titik leburnya sehingga struktur mikronya mengalami perubahan seperti pertumbuhan butir (grain growth), peningkatan densitas dan penyusutan volume, pengurangan jumlah dan ukuran pori. Kelebihan sintering adalah proses yang stabil, tidak ada pemisahan partikel yang sudah terikat dan hasil akhir yang seragam, kemurnian bahan tetap terjaga yang memungkinkan proses selanjutnya lebih mudah.

Perhitungan sifat fisik:

1) Perhitungan Susut Pemanasan (Sihite, 2008).

a. Susut Volume

$$
\frac{V_{o}-V_{t}}{V_{o}} \times 100 \%
$$

b. Susut Massa

$$
\frac{m_{o}-m_{t}}{m_{o}} \times 100 \%
$$

2) Perhitungan Densitas (Berger, 2010).

a. Bulk Densitas

$$
\mathrm{BD}=\frac{m_{t}}{V_{t}}
$$

b. Archimedes Densitas

$$
\mathrm{AD}=\frac{m_{t}}{m_{t}-m_{a}} \times \rho_{\text {air }}
$$

3) Perhitungan Porositas (Berger, 2010).

$$
1-\frac{V_{s}}{V_{t}} \times 100 \%
$$

4) volume spesimen dapat menggunakan

$$
\mathrm{V}_{\mathrm{S}}=\frac{m_{t}-m_{a}}{\rho_{\text {air }}}
$$


keterangan

$\mathrm{V}_{\mathrm{o}}=$ Volume sampel sebelum dipanaskan $\left(\mathrm{cm}^{3}\right)$

$\mathrm{V}_{\mathrm{t}}=$ Volume sampel sesudah dipanaskan $\left(\mathrm{cm}^{3}\right)$.

$\mathrm{m}_{0}=$ Massa sampel sebelum dipanaskan (gram)

$\mathrm{m}_{\mathrm{t}}=$ Massa sampel sesudah dipanaskan (gram).

$\mathrm{m}_{\mathrm{a}}=$ Massa sampel di dalam air (gram).

\section{METODOLOGI PENELITIAN}

Alat yang digunakan dalam penelitian ini antara lain neraca digital, alat press dan alat pemanas. Tahapan penelitian diawali dengan menyiapkan zeolit, tanah lempung dan arang batok kelapa lalu dilakukan pengayakan untuk mendapatkan butiran yang sama dengan ukuran 80 mesh. Selanjutnya pembuatan Adonan, pada proses ini bubuk zeolit, tanah lempung dan arang batok kelapa yang sudah satu ukuran menjadi 80 mesh selanjutnya dicampur dan ditambahkan air secukupnya kemudian diaduk hingga menjadi adonan bahan yang homogen dengan perbandingan persentase zeolit $75 \%$, tanah lempung $15 \%$ dan arang batok kelapa $10 \%$. Tahapan selanjutnya adalah proses pencetakan, setelah campuran adonan zeolit, tanah lempung dan arang batok kelapa homogen, adonan dicetak menggunakan cetakan silinder dengan material kuningan.

Ada tiga bagian cetakan yang digunakan, yang pertama adalah core dengan diameter luar $62 \mathrm{~mm}$, diameter dalam $43 \mathrm{~mm}$ dan tinggi core $63 \mathrm{~mm}$, sedangkan yang kedua adalah cavity atau as cavity dengan diameter $22 \mathrm{~mm}$ dan tinggi $66 \mathrm{~mm}$. Kemudian yang ketiga adalah pressing dengan diameter luar $43 \mathrm{~mm}$, diameter dalam $22 \mathrm{~mm}$ dan tinggi $35 \mathrm{~mm}$. Masukkan adonan dalam cetakan hingga penuh lalu tekan dengan tuas kemudian di press dengan tekanan $400 \mathrm{~kg} / \mathrm{cm}^{2}$ atau $40 \mathrm{Mpa}$ dengan penahanan waktu 5 menit. Setelah proses pengepresan selesai keluarkan green part dari cetakan, semua sampel yang dibuat melewati proses dan perlakuan yang sama.

\section{a) Sintering}

Setelah pencetakan sampel selesai, kemudian sampel dilakukan proses sintering menggunakan furnace dengan tingkat pemanasan $5^{\circ} \mathrm{C} /$ menit dan penahanan suhu sintering selama 4 jam dengan variasi suhu sintering $700^{\circ} \mathrm{C}, 800^{\circ} \mathrm{C}$ dan $900^{\circ} \mathrm{C}$

b) Pendinginan Sampel

Setelah bahan baku selesai sintering dengan variasi suhu $700^{\circ} \mathrm{C}, 800^{\circ} \mathrm{C}$ dan $900^{\circ} \mathrm{C}$ kemudian lakukan penahanan selama 4 jam, lakukan pendinginan hingga suhu kamar yaitu dengan mematikan furnace tanpa membukanya (pendinginan dilakukan di dalam furnace). Hal ini dilakukan untuk menghindari kemungkinan terjadi retakan pada sampel yang diakibatkan oleh perubahan suhu secara drastis. Setelah tercapai suhu kamar di dalam furnace ambil sampel untuk diuji dan dianalisis.

Pengujian sifat fisik yang terdiri dari susut massa, susut volume, densitas, porositas, laju aliran air dan nilai TDS (Total Dissolved Solids) dilakukan di Laboratorium Material Fakultas Teknik Universitas Wahid Hasyim Semarang dan pengujian kandungan air hasil penyaringan dilakukan di Unit Jasa Industri Laboratorium Kimia Jurusan Kimia FMIPA Universitas Negeri Semarang dengan ICPOES(inductively coupled plasma-optical emission spectrometry).

\section{HASIL DAN PEMBAHASAN}

Pada penelitian ini telah dilakukan pembuatan membran keramik zeolit, lempung dan arang batok kelapa dengan variasi suhu sintering $700^{\circ} \mathrm{C}, 800^{\circ} \mathrm{C}$ dan $900^{\circ} \mathrm{C}$. Berikut hasil karakterisasi pengujian susut massa, susut volume, densitas, porositas, laju aliran air dan nilai TDS, serta kandungan air setelah dilakukan penyaringan.

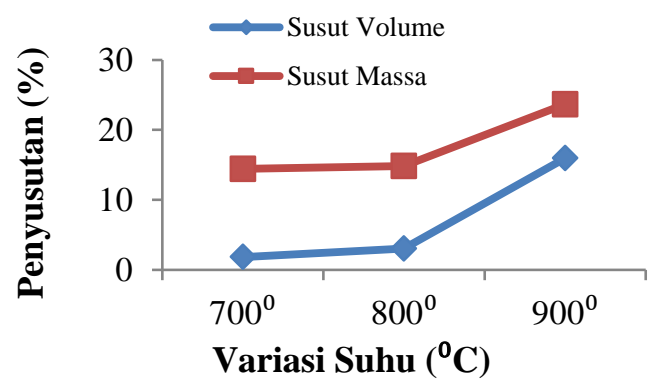

\section{Gambar 1. Grafik Susut Pemanasan}

Gambar 1. menunjukkan terjadi kenaikan penyusutan baik pada susut volume maupun susut massa, penyusutan yang signifikan terjadi pada perbandingan variasi suhu sintering $800^{\circ} \mathrm{C}-900^{\circ} \mathrm{C}$. Dari grafik dapat diketahui hasil susut volume dan susut massa berbanding lurus yaitu semakin tinggi suhu sintering maka semakin besar penyusutan terhadap volume dan massa pada material keramik tersebut, ini dikarenakan arang batok kelapa yang terdapat di dalam material keramik terbakar pada saat proses sintering dan menimbulkan rongga atau pori-pori di dalam material keramik tersebut. Sehingga berat pada 
material keramik mengalami penyusutan. Selain itu susut pemanasan menyebabkan hilangnya air yang dikandung bahan keramik dan antar butiran zeolit, tanah lempung dan arang batok kelapa yang saling mengikat.

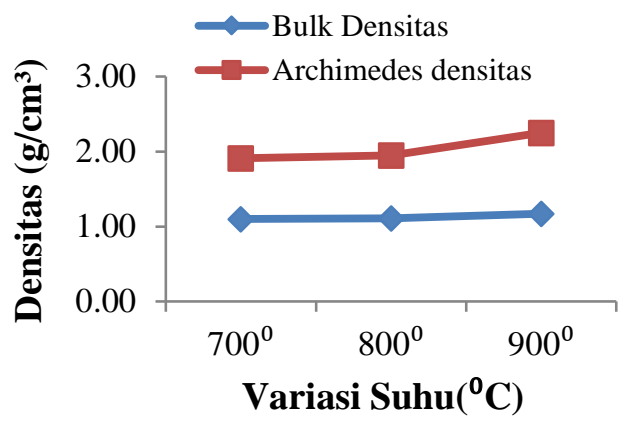

Gambar 2. Grafik densitas

Gambar 2 menunjukkan bahwa nilai bulk densitas terkecil pada perbandingan variasi suhu sintering $700^{\circ} \mathrm{C}$. Terbesar terjadi pada perbandingan variasi suhu sintering $900^{\circ} \mathrm{C}$. Jadi semakin tinggi variasi suhu sintering maka semakin tinggi nilai kerapatannya. Sedangkan pada Archimedes densitas terkecil dengan perbandingan variasi suhu sintering $700^{\circ} \mathrm{C}$. Terbesar terjadi pada perbandingan variasi suhu sintering $900^{\circ} \mathrm{C}$. Maka semakin tinggi variasi suhu sintering maka semakin tinggi pula nilai Archimedes densitas dan nilai kerapatannya semakin besar. Karena nilai densitas berpengaruh terhadap porositas dari suatu material keramik.

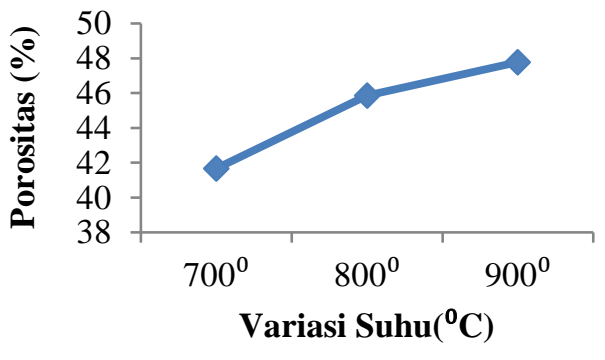

\section{Gambar 3. Grafik porositas}

Gambar 3 menunjukkan grafik porositas dimana variasi suhu sintering sangat berpengaruh terhadap hasil porositas. Sehingga hal ini dapat diketahui bahwa semakin tinggi variasi suhu sintering maka nilai porositas material tersebut akan semakin tinggi dikarenakan material tersebut terdapat banyak rongga atau pori-pori yang dihasilkan dari arang batok kelapa yang terbakar ketika proses sintering. Secara fisik penggunaan campuran arang batok kelapa juga akan berpengaruh terhadap berat maupun volume keramik tersebut.

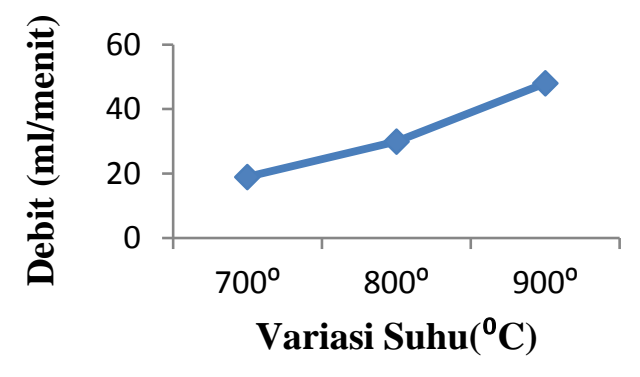

\section{Gambar 4. Pengujian Laju Aliran Air}

Gambar 4 menunjukkan grafik pengujian laju aliran air. Dimana semakin tinggi variasi suhu sintering maka semakin cepat pula laju aliran air ketika proses penyaringan. Hal ini disebabkan oleh banyaknya rongga atau poripori yang terdapat di dalam material keramik karena terbakarnya arang batok kelapa pada saat proses sintering. Terjadinya pengikatan antara zeolit alam, tanah lempung dan arang batok kelapa selama proses sintering, sehingga terjadi rongga di dalam material keramik.



\section{Gambar 5. Pengujian TDS}

Gambar 5 menunjukkan hasil pengujian TDS air mengalami penurunan nilai ppm yang dipengaruhi oleh variasi suhu sintering yang berbeda-beda. Hasil tersebut dapat diketahui bahwa semakin tinggi suhu sintering, maka semakin kecil nilai ppm dan hasil penyaringan air yang dihasilkan akan semakin baik karena nilai ppm air dapat diketahui dari tinggi rendahnya nilai ppm yang semakin kecil. Hal ini disebabkan karena arang batok kelapa sebagai karbon aktif yang sangat baik dan sebagai absorben atau penyerap zat-zat yang melewati arang tersebut. Tetapi hasil 
penyaringan ini menunjukkan nilai $\mathrm{ppm}$ air sanitasi tidak air murni ataupun layak minum.

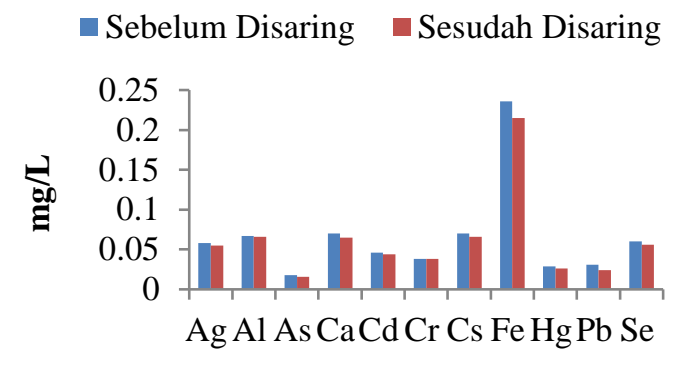

Unsur

\section{Gambar 6. Uji Kandungan Air Suhu sintering $7^{\circ 0} 0^{\circ} \mathrm{C}$}

Menurut hasil diagram diatas, kandungan $\mathrm{Ca}$ pada air hasil penyaringan dengan suhu sintering $800^{\circ} \mathrm{C}$ terlihat mengalami penurunan secara signifikan yaitu $0,007 \mathrm{mg} / \mathrm{L}$ menjadi $0,004 \mathrm{mg} / \mathrm{L}$. Selain itu, kandungan $\mathrm{Cs}$ dan Se pada air hasil penyaringan dengan suhu sintering $800^{\circ} \mathrm{C}$ juga mengalami penurunan secara signifikan yaitu $0,07 \mathrm{mg} / \mathrm{L}$ menjadi $0,054 \mathrm{mg} / \mathrm{L}$ dan $0,060 \mathrm{mg} / \mathrm{L}$ menjadi $0,04 \mathrm{mg} / \mathrm{L}$. Meskipun mengalami penurunan, kandungan Selenium (Se) dalam air tersebut masih tergolong kategori tinggi karena masih melampaui batas kadar maksimum yaitu $0,01 \mathrm{mg} / \mathrm{L}$.

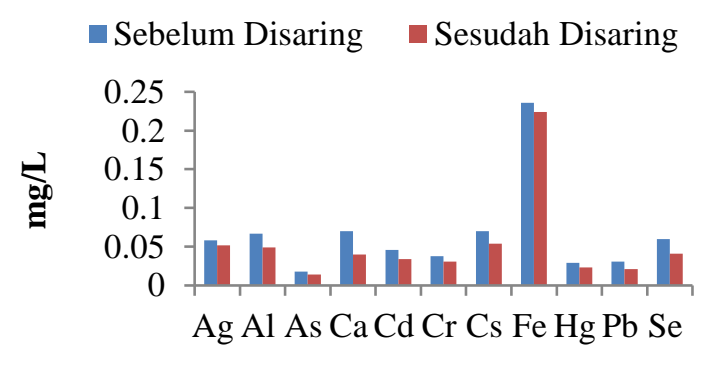

Unsur

\section{Gambar 7. Uji Kandungan Suhu Sintering $8^{800} \mathrm{C}$}

Menurut hasil diagram diatas, kandungan Ag (Perak), Al (Aluminium), As (Arsen), Ca (Kalsium), Cd (Kadmium), Cr (Krom), Cs (Sesium), Fe (Besi), Hg (Raksa), $\mathrm{Pb}$ (Timbal) dan Se (Selen) mengalami penurunan dibandingkan air sebelum dilakukan penyaringan pada air hasil penyaringan dengan suhu sintering $900^{\circ} \mathrm{C}$.

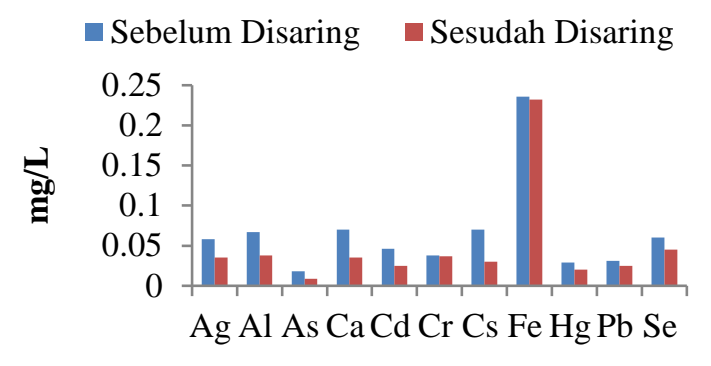

Unsur

\section{Gambar 8. uji kandungan air suhu sintering $900^{\circ} \mathrm{c}$.}

\section{PENUTUP \\ Kesimpulan}

Semakin tinggi suhu sintering maka semakin besar penyusutan terhadap volume dan massa sehingga nilai densitas dan porositas semakin tinggi. Suhu sintering memberikan pengaruh yang signifikan terhadap sifat fisik membran keramik zeolit, lempung dan arang batok kelapa.

Semakin tinggi suhu sintering maka semakin besar laju aliran airnya dan semakin rendah nilai TDS airnya. Semakin rendah nilai TDS air maka semakin baik nilai kemurnian air tersebut. Hal ini didukung oleh penurunan kandungan unsur logam yang terdapat pada air hasil penyaringan pada membran keramik zeolit, lempung dan arang batok kelapa. Pada hasil uji ICP-OES kandungan air hasil penyaringan membran keramik zeolit, lempung dan arang batok kelapa dengan suhu sintering $900^{\circ} \mathrm{C}$ menunjukkan penurunan yang signifikan terhadap unsur logam $\mathrm{Ag}, \mathrm{Al}, \mathrm{As}, \mathrm{Ca}, \mathrm{Cd}, \mathrm{Cr}$, $\mathrm{Cs}, \mathrm{Fe}, \mathrm{Hg}, \mathrm{Pb}$ dan Se dibandingkan dengan air sebelum dilakukan penyaringan dengan variasi suhu sintering. Suhu sintering memberikan pengaruh yang signifikan terhadap kandungan kualitas air hasil penyaringan pada membran keramik zeolit, lempung dan arang batok kelapa.

\section{DAFTAR PUSTAKA}

Akbary, F. (2009). Membran Zeolit Katalitik untuk Pembentukan Syngas. ... Kadar Besi oleh Media Zeolit Alam Ponorogo secara ....

Arifin, B. (2009). Penggunaan Abu Batu Bara PLTU Mpanau Sebagai Bahan Stabilisasi Tanah Lempung. SMARTek. http://jurnal.untad.ac.id/jurnal/index.php/ SMARTEK/article/view/592 
Berger, M. B. (2010). The importance and testing of density/porosity/permeability/pore size for refractories. The Southern African Institute of Mining and Metallurgy .... http://www.saimm.co.za/Conferences/Re fractories2010/101-116_Berger.pdf

Pambayun, G. S., Yulianto, R. Y. E., Rachimoellah, M., \& ... (2013). Pembuatan karbon aktif dari arang tempurung kelapa dengan aktivator $\mathrm{ZnCl} 2$ dan $\mathrm{Na} 2 \mathrm{CO} 3$ sebagai adsorben untuk mengurangi kadar fenol dalam air limbah. Jurnal Teknik .... http://ejurnal.its.ac.id/index.php/teknik/ar ticle/view/2437

Salamah, S. (2008). Pembuatan Karbon Aktif dari Kulit Buah Mahoni dengan Perlakuan Perendaman dalam Larutan $\mathrm{KOH}$. Prosiding Seminar Nasional Teknoin. https://journal.uii.ac.id/Teknoin/article/vi ew/2075

Sebayang, P., \& Tetuko, A. P. (2012). 99 PEMBUATAN BAHAN FILTER KERAMIK BERPORI BERBASIS ZEOLIT ALAM DAN ARANG SEKAM PADI. Teknologi Indonesia. http://203.160.128.146/index.php/JTI/arti cle/view/9

Sihite, D. R. (2008). Pembuatan dan karakterisasi bahan keramik berpori dengan aditif sekam padi yang digunakan sebagai filter gas buang. USU Medan.

Tambunan, T. D. (2008). Pembuatan keramik berpori sebagai filter gas buang dengan aditif karbon aktif. Tesis Universitas Sumatera Utara ....

Wahyuni, E. T. (2010). Limbah bahan beracun dan berbahaya (B3): permasalahan dan upaya pengelolaannya dengan bahan alam. text. https://repository.ugm.ac.id/93535/

Wendari, T. P., Arief, S., Mufti, N., Suendo, V., Prasetyo, A., \& ... (2019). Synthesis, structural analysis and dielectric properties of the double-layer Aurivillius compound Pb1-2xBi1. 5+ 2xLa0. 5Nb2xMnxO9. Ceramics https://www.sciencedirect.com/science/ar ticle/pii/S0272884219313987 